\title{
O Pensamento latino-americano nos anos 1960 e 1970: Debates, ideias, conceitos
}

\begin{abstract}
Alexandre Queiroz ${ }^{1}$
Resumo: Buscamos apresentar um panorama histórico do que consideramos a afirmação de um pensamento latino-americano entre as décadas de 1960 e 1970. Propomos tecer uma abordagem crítica, transnacional, apoiando-se na História Intelectual, utilizando manifestos, conclusão de conferência e ensaios como marcos delineadores do debate que se desenvolveu na América Latina no período. Tal debate se perfaz no embate de ideias entre os filósofos Augusto Bondy e Leopoldo Zea e envolveu concepções sobre a História das Ideias e o "lugar das ideias" na América Latina, que abordamos na primeira parte do artigo, bem como a Teologia da Libertação e a Filosofia da Libertação, focados na segunda parte. No contexto da Guerra Fria e do crescimento do discurso autoritário na região, o contato com o Marxismo, a preocupação com uma epistemologia atrelada à realidade latino-americana, o ideal de integração da região e uma perspectiva histórico-revolucionária, libertadora, assim como suas contradições, pautaram as manifestações críticas consideradas.
\end{abstract}

Palavras-chave: Pensamento latino-americano; História Intelectual; Libertação.

\section{Latin American Thought in the 1960s and 1970s: Debates, ideas, concepts}

\begin{abstract}
This article aims to present a historical overview of what we consider the affirmation of a Latin American thought between the 1960s and 70s. Proposing a critical approach, transnational, based on Intellectual History, were used manifests, conference conclusion and essays like delineating points of the debate that developed in Latin America in the period. This debate took place in the conflict of ideas between the philosophers Augusto Bondy and Leopoldo Zea and involved conceptions about the History of Ideas and the "place of the ideas" in Latin America, which we discussed in the first part of the article, as well as Liberation Theology and Liberation Philosophy, focused on the second part. In the context of the Cold War and the authoritarian discourse growth in the region, the contact with Marxism, the concern with an epistemology linked to Latin American reality, the integration ideal of the region and a libertarian, historical-revolutionary perspective, as well as it's contradictions, guided the critical manifestations considered.
\end{abstract}

KeyWords: Latin American Thought, Intellectual History, Liberation.

Artigo recebido em: 19/06/2017

Artigo aprovado para publicação em: 18/11/2017

\footnotetext{
1 Mestrando em História na Escola de Filosofia, Letras e Ciências Humanas (EFLCH), campus Guarulhos, Universidade Federal de São Paulo (UNIFESP), Brasil. Esse artigo é um desdobramento da pesquisa de mestrado intitulada A Revolução no Paraíso: ressignificações do conceito de Libertação na Igreja latino-americana (1968-1979), financiada pelo CNPq. E-mail: alexandrezqueiroz@gmail.com
}

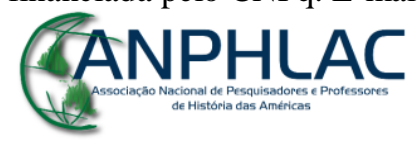

Revista Eletrônica da ANPHLAC, ISSN 1679-1061, №. 24, p. 324-353, Jan./Jun., 2018.

http://revista.anphlac.org.br 


\section{Introdução}

No contexto da Guerra Fria, a preocupação com uma epistemologia atrelada às questões da realidade latino-americana, o ideal de integração da região e uma perspectiva histórico-revolucionária, libertadora, pautaram debates sobre a existência e validade de um pensamento latino-americano. Diálogos com o Marxismo ganharam notório impulso na América Latina após a Revolução Cubana (1959), passando pelo paradigma da "via chilena" nos anos 1970, em flagrante confronto com o crescimento do discurso autoritário, expresso nas Ditaduras que chegavam ao poder em muitos países da região. Foi nesse ambiente que o debate intelectual sobre a afirmação desse pensamento foi considerado, pelo prisma histórico e metodológico. Tais ideias foram imbricadas a movimentos que buscaram imprimir uma feição engajada e latinoamericana a diferentes áreas de conhecimento. Portanto, o que denominamos a afirmação de um pensamento por e para latino-americanos baseia-se na sua pluralidade, abrangendo díspares caminhos trilhados, rejeitando uma trajetória homogênea e linear, mas que se articulou a partir pressupostos comuns. Colocá-los lado a lado, nesse artigo, nos parece oportuno para apresentar um panorama histórico.

Selecionamos manifestos, conclusão de conferência e ensaios como marcos delineadores do debate que se desenvolveu na América Latina no período. Sabemos da limitação de não abordamos as muitas variantes desses movimentos. Todavia, essa escolha decorre da proposta delimitada, de circunscrever esses movimentos, de forma a pautar ou fundamentar correntes teóricas, estabelecendo diálogos e perscrutando o que consideramos um processo que desenvolveu críticas confluentes na América Latina entre finais da década de 1960 e ao longo dos anos 70.

Assim, baseamo-nos em pressupostos da História Intelectual, compreendida como a "[...] exploração da produção douta realizada pelas elites letradas do passado, enfocada a partir de uma perspectiva que considera a própria condição de inteligibilidade histórica dessa produção...” (MYERS, 2016, p. 24-25). ${ }^{2}$ Em franco crescimento na historiografia latino-americana nas últimas décadas, entrelaçou-se com

\footnotetext{
${ }^{2} \mathrm{O}$ autor destacou que por douto considerou uma linguagem elaborada, complexa, e, por elite, a especialização nos recursos simbólicos necessários na construção do discurso douto (por exemplo, operários que escrevem um panfleto) - considerando que há a tendência à identificar essa elite com setores dominantes da sociedade como uma tendência contingente, mas não uma determinação necessária.
}

\section{GANPHLAC}

Revista Eletrônica da ANPHLAC, ISSN 1679-1061, №. 24, p. 324-353, Jan./Jun., 2018.

http://revista.anphlac.org.br 
as novas perspectivas que ultrapassam a fronteira do Estado-Nação moderno (NORONHA DE SÁ, 2016, p.11). O viés transnacional tem contribuído para o redimensionamento de questões anteriormente restritas ao espaço nacional, ainda que não o anule (WEINSTEIN, 2013, p. 27). Nesse sentido, a circulação de ideias, os usos e sentidos da linguagem, a atenção às instituições e movimentos, os atores e meios de produção e o debate intelectual, entre outros, têm pautado parte da produção historiografia contemporânea na América Latina, redefinindo limiares estanques.

$\mathrm{O}$ artigo se divide em duas partes. Na primeira, abordamos o embate entre os filósofos Augusto Salazar Bondy e Leopoldo Zea, em 1968-9, sobre a existência de um pensamento latino-americano; concepções sobre a História das Ideias, que teve na figura de Zea um dos grandes expoentes do movimento; e a atuação dessas ideias na América Latina, abrangendo o debate sobre as "ideais fora do lugar" suscitado por Roberto Schwarz, no Brasil. Na segunda parte, consideramos o desdobramento dessa perspectiva crítica no pensamento teológico e filosófico, respectivamente, dissertando sobre a Teologia da Libertação e a Filosofia da Libertação. Ambas elencaram o conceito de Libertação como paradigma da reflexão crítica, demarcando um movimento engajado e orientado na sua projeção. Nas Considerações Finais esboçamos algumas críticas e limitações desse processo, buscando contextualizá-lo e historicamente compreendê-lo.

\section{Bondy, Zea e o lugar das ideias na América Latina}

1968 foi um ano transformador em muitos sentidos, em muitos lugares. Podemos considerar suas turbulentas manifestações analisando o embate de ideias no período. Nesse ano, o filósofo peruano Augusto Salazar Bondy publicou um texto que reverberou de forma decisiva na afirmação de um pensamento latino-americano. A resposta imediata ao texto ocorreu no ano seguinte, redigida pelo filósofo mexicano Leopoldo Zea, e perpetuou-se ao longo das décadas seguintes na afirmação epistemológica e do campo disciplinar da História das Ideias no subcontinente. A questão sobre o pensamento latino-americano já causava certo mal-estar em círculos intelectuais antes do debate entre Zea e Bondy. No IV Congresso Interamericano de Filosofia (Buenos Aires), a questão da existência de um pensamento próprio latinoamericano não foi elencada no debate porque colocaria em dúvida a capacidade dos

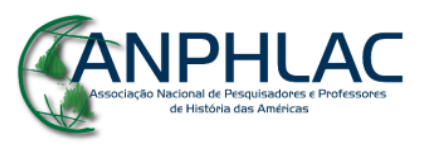

Revista Eletrônica da ANPHLAC, ISSN 1679-1061, №. 24, p. 324-353, Jan./Jun., 2018.

http://revista.anphlac.org.br 
filósofos latino-americanos de se congregarem em um ambiente autenticamente filosófico (CARVALHO, 2011, p. 185).

Não compete aos nossos objetivos expor toda a argumentação dos filósofos, erudita e extensa, mas apontar elementos desse debate que ajudam a esclarecer qual a atmosfera e sob qual parâmetro se estruturou esse diálogo filosófico em relação à História das Ideias e àqueles que buscavam um caminho próprio de assimilação, apropriação e fomento de uma crítica das ideias à realidade latino-americana.

Em 1968, Augusto Salazar Bondy escreveu dois textos sobre a "cultura de dominação", como considerou o autor: La cultura de la dominación e ¿Existe una filosofia de nuestra América?. Ambos apresentavam a tese de que a "cultura de un pueblo dominado es por necessidad de dominación e inauténtica." (SOBREVILLA, 2014, p. 12). Inserido nos debates sobre a Libertação latino-americana, tendo se inclinado para o âmbito cultural e educacional, Bondy foi designado membro, e depois presidente, de uma comissão encarregada da reestruturação educacional no Peru, após o golpe militar do general Velasco Alvorado em 1968, que inaugurou a particularidade do regime militar reformista. Salazar Bondy almejava uma educação que libertasse os peruanos da cultura de exploração, sendo fortemente influenciado pelo pedagogo brasileiro Paulo Freire (SOBREVILLA, 2014, p.18-19).

Todavia, no que compete ao seu mais aludido texto, Augusto Bondy expõem no título de sua publicação a questão que norteou sua exposição: ¿Existe una filosofia de Nuestra América?. Tendo como objeto o pensamento filosófico hispano-americano ${ }^{3}$, dividiu sua argumentação em três partes: Processo, Debate e Interpretação. Bondy fez uma compilação do pensamento latino-americano e as suas diversas influências e manifestações “copiadas” como a Ilustração, o Romantismo, o Positivismo e outros. Concluiu que o pensamento europeu foi tomado como referência por nossos intelectuais, tendo esse pensamento chegado sempre em defasagem e de forma estranha à América: "ésta tiene así el carácter de un arból transplantado, no de una planta que surgiera de la conjunción de factores propicia a um brote original y vigoroso de pensamiento.” (BONDY, 1968, s./p.). A recepção dessas ideias seria a marca candente

\footnotetext{
${ }^{3}$ Bondy, logo no começo do texto, explicou que restringiu sua análise ao pensamento hispano-americano, embora julgasse que muitas das considerações feitas poderiam ser estendidas ao Brasil e, consequentemente, à América Latina. (BONDY, 1968, s./p.) Concordamos com o autor e, tendo em vista o debate maior em que buscamos problematizar a fala do filósofo peruano, optamos por usar o termo "latino-americano" e analisá-lo tendo como parâmetro todo o subcontinente.
}

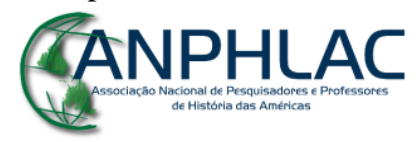

Revista Eletrônica da ANPHLAC, ISSN 1679-1061, №. 24, p. 324-353, Jan./Jun., 2018.

http://revista.anphlac.org.br 
da História filosófica latino-americana mas, como elas não lhe eram próprias, o autor considerou que essas ideias estariam constantemente "fora do lugar". 4

O autor rememorou as considerações do filósofo oitocentista argentino Juan Bautista Alberdy sobre a necessidade de desenvolver um pensamento próprio no subcontinente, identificando a mesma angústia intelectual em José Vasconcelos, Mariátegui e outros intelectuais no século XX. Bondy também expôs a imagem oposta desse raciocínio, debatendo com aqueles que defendiam a existência de um pensamento latino-americano, como o espanhol exilado no México José Gaos (mestre de Zea), Samuel Ramos e o próprio Leopoldo Zea (que escreveu o texto de resposta no ano seguinte). O "diagnóstico" de Augusto S. Bondy baseia-se na diferenciação conceitual de originalidade, genuinidade ou autenticidade e peculiaridade. Não usaremos esses termos na análise dos textos por julgar que pouco contribuem para o entendimento das questões elencadas. De qualquer forma, foi taxativo ao afirmar que "[...] no hay hasta hoy un pensamiento riguroso, auténtico y capaz de nutrise de su própria savia doctrinaria.” (BONDY, 1968, s./p.).

A causa dessa falta de condições de empreender suas próprias ideias e incorrer no erro de fazer uma cópia ruim dos outros, para Bondy, ocorreria em virtude de uma cultura de dominação existente na América Latina, fruto da condição dependente e subdesenvolvida da região. A saída para esse dilema estaria resguardada em uma nova interpretação do que seria a revolução, levando em conta a realidade latino-americana. Bondy assumiu a dialética como forma de leitura da realidade e superação da dependência, estando também envolto no processo que rejeitava o desenvolvimentismo.

[...] el hombre, en ciertas circunstancias - no frecuentes ni previsibles - salta por encima de su condición actual y transciende en la realidad hacia nuevas formas de vida, hacia manifestaciones inéditas que perduran o darán frutos en la medida en que el movimiento iniciado pueda extenderse y provocar una dialéctica general, una totalización de desenvolvimiento, eso que en el terreno político-social son las revoluciones. (BONDY, 1968, s./p.)

Por conseguinte, Salazar Bondy entrelaçou a constatação do subdesenvolvimento com a condição de gênese de um pensamento autêntico, ensejando

\footnotetext{
4 "Muchas instituciones - seguramente todas las que tienen fuerte resonancia social - poseen signo distinto das que declaran y la mayoría de las ideas cobren comúnmente un sentido extraño y aun opuesto al significado original que oficialmente se reconoce." (BONDY, 1968, s./p.).
}

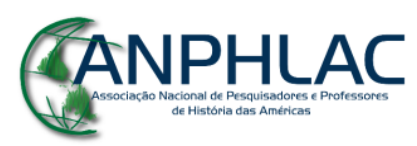

Revista Eletrônica da ANPHLAC, ISSN 1679-1061, №. 24, p. 324-353, Jan./Jun., 2018.

http://revista.anphlac.org.br 
as circunstâncias que propiciariam uma revolução. É possível constatar também que, embora não tenha assumido uma causa ideológica demarcada (como a socialista), o peruano redigiu um texto politicamente engajado, tendo diálogos velados com a teoria Marxista. A forma como ele entendeu a eclosão da revolução nas condições da América Latina atesta isso. Mas a conclusão do texto, o aporte à superação do subdesenvolvimento, também revela uma leitura tradicional das ideias enquanto objeto histórico. Consideramos que Bondy assimilou a teoria da superestrutura, ao vincular a necessidade de transformação socioeconômica para que as ideias reflitam essa mudança na sociedade. "La constitución de un pensamiento genuino y original y su normal desenvolvimiento no podrán alcanzarse sin que se produzca una decisiva transformación de nuestra sociedad mediante la cancelación del subdesarrollo y la dominación." (BONDY, 1968, s./p.). As ideias seriam condicionadas pela mudança da base que as sustentasse e difundisse, o que salienta certo descuido com a dinâmica interna das ideias - que tendo sido abordadas, metodologicamente, como expressões com relativa autonomia e na dinâmica histórica do pensamento latino-americano.

A exposição de Bondy foi contestada já em 1969 quando o filósofo mexicano Leopoldo Zea publicou La filosofia americana como filosofía sin más. Zea teve um papel central na articulação da História das Ideias e era professor de filosofia na UNAM (Universidade Nacional Autônoma do México). ${ }^{5}$ Inicialmente um pesquisador da filosofia mexicana ${ }^{6}$, a partir dos anos 1940 e 50 ampliou seu escopo espacial e temático, passando a abranger temas concernentes à América Latina e privilegiando as ideias como objeto de suas investigações. Essa nova postura do mexicano abriu caminho para uma nova leitura da realidade latino-americana centrada na afirmação de uma identidade histórica do subcontinente. Negando a universalidade na Filosofia, para assim afirmar o particular e nela encontrar o que propõe ser uma filosofia humanista e histórica, Zea empreendeu uma nova Filosofia da História na América Latina e centrou a libertação, em perspectiva filosófica, como cerne dessa reflexão. Dessa forma, a proposta de uma Filosofia da Libertação, a partir da proposta de Leopoldo Zea, “(...) pariendo de la circunstancia que es la dependencia, trata de influir sobre esa realidad

\footnotetext{
${ }^{5}$ Zea teve destacada participação na institucionalização dos estudos latino-americanos na UNAM, tendo editado revistas, publicados diversos livros, copilado fontes e dirigido instituições dedicadas ao estudo da região.

${ }^{6}$ Destacamos sua consagrada tese de doutorado em Filosofia na UNAM, defendida em 1944 e orientada por José Gaos, intitulada Apogeo y decadencia del positivismo en México.
}

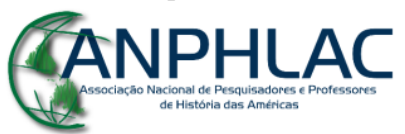

Revista Eletrônica da ANPHLAC, ISSN 1679-1061, №. 24, p. 324-353, Jan./Jun., 2018.

http://revista.anphlac.org.br 
para transfórmala hacia cada vez mayor independencia." (WEINBERG, 2014-2015, p.11).

A resposta de Zea também serviu como uma espécie de manifesto e ajudou na afirmação epistemológica e disciplinar da História das Ideias - podemos citar a publicação da UNESCO sobre a História das Ideias como um marco desse circuito intelectual $^{7}$. Também corroborou espaços de atuação político-social que se embasavam nos pressupostos desses intelectuais, que buscavam legitimar o lugar do pensamento latino-americano como uma modalidade própria, e necessária, para o desenvolvimento e integração da região.

Ao responder a questão da existência ou não de um pensamento próprio, Leopoldo Zea afirmou que essa pergunta já contém a resposta a essa inquietação, “[...] no somos capaces de reconocer que con el planteamento de esta interrogación estamos ya haciendo una filosofia que parte de nuestra problemática" (ZEA, 1969, s./p.). Por conseguinte, o filósofo ordenou sua exposição por meio da negação da questão (a existência do pensamento próprio) para então erigir o que ele delimitou como o pensamento próprio da América Latina, nas bases do projeto disciplinar da História das Ideias. Zea, retomando o debate entre Sepúlveda e Las Casas (Questão de Valladolid), dissertou sobre a forma como a filosofia europeia buscou desumanizar o homem latinoamericano. Essa constatação é importante na sua argumentação, visto que, a partir dela, Zea depreendeu a forma como a filosofia latino-americana incorporou um sentimento de inferioridade. Doravante, demonstrou que, para ele, a Filosofia era uma forma privilegiada de mostrar a humanidade dos homens, e buscou sustentar que essa expressão da humanidade já estava presente na história filosófica da América Latina. Assumida essa posição, Zea questionou o "centro", atacando a posição conferida às ideias europeias como referenciais, universais e dominantes.

As grandes expressões do pensamento latino-americano, percorrendo o vácuo daquilo que Zea classificou como uma falsa questão, também se manifestaram naqueles

\footnotetext{
${ }^{7}$ Sétimo livro da coleção América Latina en su cultura, publicada pela editora Siglo Vientiuno em 1986, por uma iniciativa da UNESCO. Os outros volumes da série são: América Latina en su literatura (1972) - Cood. César Fernandéz Moreno; América Latina en su Artes (1974) - Cood. Damián Bayón; América Latina en su música (1975) - Cood. Isabel Aretz; América Latina en su arquitectura (1977) - Cood. Damián Bayon e Paolo Gasparini; América Latina e sus lenguas indígenas (1983) - Cood. Bernard Pottier; América Latina e Bibliografía general de las artes del espetáculo em América Latina (1971) por Horácio Jorge Becco.
}

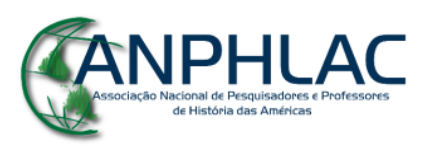

Revista Eletrônica da ANPHLAC, ISSN 1679-1061, №. 24, p. 324-353, Jan./Jun., 2018.

http://revista.anphlac.org.br 
que negaram a existência de um pensamento próprio, a exemplo do clássico texto de Mariátegui Existe un pensamiento hispanoamaericano? (1925), ou dos escritos de Juan Batista Alberdi, José E. Rodó, José Vasconcelos, Alejandro Korn, Che Guevara, entre outros. Porém, estes não devem ser tomados como filósofos destacados pelo desenvolvimento de uma filosofia produzida na América Latina. Zea dilatou esse campo ao adentrar a questão da universalidade/particularidade em que se desenvolveriam as ideias. A América Latina também comungaria das grandes ideias universais, e o autor buscou na dialética do local/universal a expressão de sua humanidade em diálogo com os outros povos. É na universalização do sentido de humanidade que residiria a possibilidade de fundamentar uma filosofia atrelada à realidade.

Muitas proposições, apesar das conclusões distintas, são comuns a ambos os filósofos, Bondy e Zea. Entre elas, a crítica à assimilação de uma suposta inferioridade latino-americana; a insistência em romper com o Eurocentrismo; a necessidade de desenvolver uma filosofia latino-americana; e a importância do estudo da História das ideias. Entretanto, a argumentação de Bondy acabou reforçando o caráter eurocêntrico que ele criticou pelo fato dos parâmetros de sua análise estarem vinculadas ao pensamento europeu. Tendo procurando o alento das ideias próprias, acreditamos que se debruçou sobre o passado incorrendo no erro que criticou: olhar a América pela perspectiva da Europa. É significativo que, ao concluir a segunda parte do seu texto, sintetizando de certa forma sua posição, após afirmar que não há motivos para acreditar que exista uma filosofia latino-americana, o filósofo deixou evidente sob qual posição ele elaborou seu julgamento:

[...] frente al pensamiento ocidental que conocemos y que estamos acostumbrados a acoger, pueda ponorse, com igual carácter y rango, es decir, como instrumento eficaz de reflexión y como alimento doctrinario, ese producto endeble y reme dado que elaboran nuestros filósofos. (BONDY, 1968, s./p.)

Por outro lado, o programa da História das Ideias na América Latina estaria intrinsecamente ligado à afirmação de um pensamento próprio no subcontinente. $\mathrm{Na}$ passagem seguinte, Zea desconstruiu o que consideramos uma questão parecida com o debate deflagrado sobre a tese das "ideias fora do lugar" (o qual será abordado posteriormente), e elencou o que seria a missão inicial depositada sobre aqueles que empreenderam uma História das Ideias na América Latina:

\section{GANPHLAC}


[...] aquel que busca en las expresiones del pensamiento latinoamericano sino una relación de semejanza, no encuentre en estas expresiones sino distorsiones, malas copias, incomprensión y, con ello, lo que considera un grave signo de inmadurez. Otro ha sido el punto de vista de quienes no buscan la semejanza sino la relación que esta filosofía, o filosofías importadas, guardan con la realidad latinoamericana. Esto es, la forma como aquéllas, consciente o inconscientemente, son adaptadas a ésta. Tal ha sido, insistimos, la preocupación encaminada a hacer una historia de las ideas de esta América. (ZEA, 1969, s./p.)

O contato com a realidade e seu comprometimento com ela seriam as marcas da filosofia latino-americana. Dessa forma, o estudo das ideias deveria levar em conta o historicismo que as delimitaria. Zea citou a leitura de José Ortega y Gasset, historiador espanhol do século XIX, como grande referência nesse quesito, e também seu orientador na UNAM, José Gaos. O aporte de uma nova filosofia europeia também endossou sua perspectiva. A filosofia existencialista teve grande destaque no texto, e autores como Sartre e Levi-Strauss foram bastante citados. A angústia do pós Segunda Guerra, a preocupação com a realidade sociopolítica e a afirmação de um tipo de humanismo, dialogaram com o contexto de formulação de ideias que fundamentou o reconhecimento e desenvolvimento de um pensamento latino-americano. Nesse ponto, consideramos que Zea abriu um diálogo interessante com os estudos Pós-coloniais ${ }^{8}$. Ao afirmar que estava sendo superado um sentimento de inferioridade, as lutas anticoloniais e o reconhecimento da humanidade do outro, Zea enveredou para um terceiromundismo, mas que não se contradiz com a afirmação de uma identidade latinoamericana. Na lógica da Guerra Fria, a polaridade entre os centros de poder (sendo que nenhum deles era a Europa), também ajuda a entender a necessidade de afirmação de um diálogo Sul-Sul, entre América Latina, África e Ásia, no bojo de uma luta antiimperialista e terceiro-mundista 9 .

A questão da vinculação da dependência a não autenticidade da filosofia latinoamericana foi rebatida por Leopoldo Zea ao afirmar que "La inautenticidad de la filosofia no es, así, un problema de subdesarrollo [...] Inauténtica es la filosofia que crea la idea del Hombre que es la negación del hombre mismo.” (ZEA, 1969, s./p.). A

\footnotetext{
${ }^{8}$ Zea citou largamente o psiquiatra e filósofo Frantz Fanon. Também esboçou algumas ideias que foram expostas, e melhor desenvolvidas, em O Orientalismo, de Edward Said. "El hombre de la modernidad insatisfecho [...] busco en el mundo primitivo, el mundo natural, la imagen del hombre que aspiraba a ser y que no era." (ZEA, 1969, s/p).

9 "El latinoamericano, el asiático, el africano no eran hombres, sino pura y simplemente objetos de explotación [...] El occidental pecaba de inhumanidad al no tratar a los otros como hombre sino como objetos". (ZEA, 1969, s./p.).
}

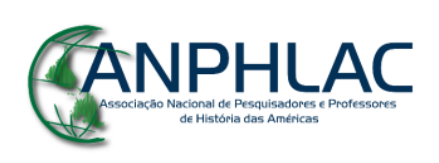

Revista Eletrônica da ANPHLAC, ISSN 1679-1061, №. 24, p. 324-353, Jan./Jun., 2018.

http://revista.anphlac.org.br 
revolução preconizada por Zea foi enunciada como consequência de uma mudança de pensamento sobre a realidade latino-americana. Constatado o subdesenvolvimento, as ideias empreenderiam uma mudança na sociedade, em que o pensamento latinoamericano seria modificado e parte dessa mudança produziria um novo homem no subcontinente. Destoou, portanto, do programa revolucionário de Augusto Bondy.

O papel conferido às ideias na sociedade é outro ponto de desencontro nos textos dos dois filósofos. Enquanto Bondy, de certa forma, reforçou a tese de estrutura /superestrutura da teoria Marxista, Zea operou por outros caminhos. Como seu texto objetivou afirmar que existia um pensamento latino-americano, as ideias não teriam uma condição subordinada à estrutura. Ambos atestam e condenam o subdesenvolvimento da região, mas Zea conferiu às ideias a condição de transformação da realidade latino-americana. Postulou-se que as ideias poderiam canalizar a real transformação da América Latina, num movimento coordenado de superação do subdesenvolvimento e irmandade do pensamento latino-americano pela perspectiva (e luta) do que, no final dos anos 1960, denominou-se libertação.

Na linha defendida pelo historiador Eugênio R. de Carvalho, o debate entre Zea e Bondy teve como grande consequência a maior difusão das diretrizes de Zea, além de ressaltar, como objeto de investigação a

\footnotetext{
[...] lógica interna dos processos histórico-culturais latino-americanos de adaptação e assimilação das ideias oriundas da matriz filosófica europeia ou ocidental, redefinindo e flexibilizando os próprios conceitos de originalidade e autenticidade filosóficas. (CARVALHO, 2013, p. 200)
}

A História das Ideias na América Latina teve, nesse sentido, seu grande momento de afirmação.

O engajamento na causa das ideias próprias latino-americanas, mesmo pela apropriação das ideias de "fora" (endossando a perspectiva de que não haveria um centro), se manifestou no repertório da História das Ideias. Esse repertório consistiu em uma releitura da identidade latino-americana e na identificação dessa leitura da realidade do subcontinente com um ideal de integração, resguardados em um passadopresente-futuro comumente compartilhado. Por conseguinte, cabe-nos elencar os principais postulados da História das Ideias e entender os meandros desse processo. A História das Ideias na América Latina desenvolveu-se após a Segunda Guerra Mundial e teve como percussores os filósofos mexicano Leopoldo Zea, o uruguaio Arturo Ardao e

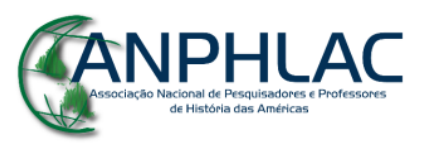

Revista Eletrônica da ANPHLAC, ISSN 1679-1061, №. 24, p. 324-353, Jan./Jun., 2018.

http://revista.anphlac.org.br 
o argentino Arturo Andrés Roig, sendo o México o centro privilegiado, tanto no âmbito institucional como no trânsito de ideias deste movimento latino-americano.

Na historiografia latino-americana entre os anos 1960 e 80, momento que Myres elencou como de cristalização de uma História das ideias que antecedeu e serviu de base para a História Intelectual, havia duas grandes correntes paradigmáticas de abordagem das ideias: a mais voltada à História Cultural e a tradicional História das Ideias (respectivamente a anglo-saxônica History of ideas, de Lovejoy, e a alemã Kulturgeschichte - numa "ressonância tardia" na América Latina), além da existência de obras "canônicas da historiografia", que serviram como antecedentes do atual História Intelectual (MYRES, 2016, p. 40). A História das Ideias se situa nesse momento de transição, podendo também ser arrolada no processo de consolidação de um pensamento latino-americano.

Santos, ao analisar a trajetória de Leopoldo Zea, Arthuro Ardao e João Cruz Costa, apontou a formação de uma rede de intelectuais latino-americanos de história das ideias filosóficas a partir da década de 1940. Essa rede ganhou contornos com a viagem de Leopoldo Zea pela América Latina entre 1945 - 46 e uma face institucional com a criação do Comité de Historia de las ideas en América Latina, formada e presidida por Zea no México, em 1947. Para ingressar no Comitê, era necessário defender que as ideias não eram abstratas e imutáveis e historiar as ideias que se relacionassem com o desenvolvimento cultural da América (SANTOS, 2016, p. 87). O uso do historicismo, isso é, uma preocupação com a relação intrínseca das ideias com o processo histórico, pode ser apontado como um elemento caracterizador dessa rede, ainda que tenha sido empregado de formas diferentes pelos seus pares. Dessa forma, ia se consolidando e difundindo a produção sobre História das ideias na América Latina.

Dissertando sobre o movimento da História das Ideias, Carvalho fez uma digressão para demarcar a historicidade desse processo. A História das Ideias partiu da proposta de uma filosofia própria para a América Latina, nos marcos de um historicismo filosófico que teve em Ortega y Gasset um referencial. Essa proposta originou uma filosofia da história latino-americana, que tinha como característica a temporalidade alargada de suas considerações histórico-filosóficas e uma perspectiva teleológica (CARVALHO, 2009, p. 62). Na historiografia latino-americana, o historiador e sociólogo colombiano Jaime J. Uribe situou a História das Ideias como

\section{CANPHLAC}

Revista Eletrônica da ANPHLAC, ISSN 1679-1061, №. 24, p. 324-353, Jan./Jun., 2018.

http://revista.anphlac.org.br 
pertencente ao alargamento temático da quarta fase histórica da escrita da História na região ${ }^{10}$ que, junto com a História Econômica, seriam os setores que mais despontaram na historiografia ${ }^{11}$ e influenciaram a escrita da História no período.

Leopoldo Zea identificou como uma das marcas constitutivas e diferenciadoras do pensamento latino-americano o diálogo com a realidade, com os problemas que passaram a ser visíveis e problematizados nos ambientes intelectuais, os quais atestariam o engajamento desse pensamento, embora, às vezes, prevaleceu uma visão utilitária dessa premissa. A passagem do debate sobre a existência do pensamento latino-americano para a reflexão sobre a práxis libertadora que a História das Ideias proporcionaria foi uma transição importante. A forma como a História das Ideias interpretou a realidade latino-americana e postulou uma Filosofia da História e um pensamento próprio baseou-se numa visão dialética. A dialética foi uma condição essencial para se compreender como o movimento buscou uma práxis libertadora. Grande expoente da História das Ideias,

[...] A partir de los años sesenta, Zea comienza una reflexión sobre las estructuras del dialogo intercultural y las relaciones estratificadas entre los hombres: primer y tercero mundo, centro y periferia, hegemonía y dependencia." (WEINBERG, 2014-2015, p. 23)

As etapas de investigação das ideias enquanto objeto foram expostas por Roig. Inicialmente, compreender-se-ia a ideia como "[...] elemento significativo que integra una estructura más amplas", sendo essa delimitação próxima da acepção de "conceito" do historiador alemão Koselleck. Aplicar-se-ia um "tratamento dialético" para se abrir "[aos] grandes movimientos de liberación e integración latinoamericanos." Essa investigação deve ater-se a "unidade do processo histórico latino-americano" e levar em conta, simultaneamente, "os problemas concretos latino-americanos" e as respostas dos “campos epistemológicos específicos” (Filosofia, Pedagogia, História, etc.). O respeito à consciência social dos agentes dessas ideias também foi citado (ROIG, 1986, p. 61). Podemos então concluir que alguns pontos do Marxismo foram incorporados na análise

10 Esse texto tem importância estratégica por compor o volume da América Latina en su ideas, dissertando sobre a historiografia da região. Permite compreender de que forma o grupo da História das Ideias buscou se situar e firmar no panorama historiográfico latino-americano (URIBE, 1986, p. 23-31).

11 Autores brasileiros tiveram destaque nesse período assinalado por Uribe. Florestan Fernandes, Fernando Henrique Cardoso, Boris Fausto, Celso Furtado, entre outros, foram citados nessa virada historiográfica do pós Segunda Guerra Mundial. (URIBE, 1986, p. 30).

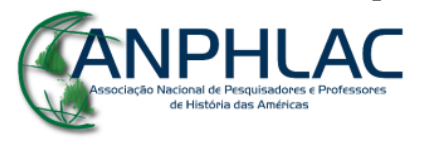

Revista Eletrônica da ANPHLAC, ISSN 1679-1061, №. 24, p. 324-353, Jan./Jun., 2018.

http://revista.anphlac.org.br 
da História das ideias: a visão dialética e a indissociabilidade da teoria e da práxis são bem veementes - assim como seu intrínseco engajamento.

Entretanto, seria um erro reduzir o campo epistemológico da História das Ideias apenas ao rótulo de "contatos com o Marxismo". Almejou-se, seguindo as linhas propostas pelo próprio movimento, e em certo sentido em desacordo com vertentes do Marxismo, buscar a consciência social dos agentes que debatiam o conceito de Libertação, de forma que tensões, clivagens, releituras, apropriações, continuidades, ressignificações e contradições fossem repertórios comuns na análise das ideias.

O tema da apropriação das ideias foi muito pautado no Brasil após a publicação, em 1973, de As Ideias fora do lugar ${ }^{12}$ pelo crítico literário Roberto Schwarz, que reverberou muitas das prerrogativas que se debatiam e formulavam no âmbito da História das Ideias. O artigo de Schwarz suscitou grande polêmica pelo que consideramos uma falsa questão ${ }^{13}$, a suposta incompatibilidade das ideias quando transplantadas para outro ambiente, que não o original, isto é, ideias fora do lugar. Mais especificamente a conjunção liberalismo/escravidão presente nos Trópicos. Assim, compreendemos que o debate brasileiro sobre "As ideias fora do lugar" complementou as considerações críticas que se estabeleciam na América Hispânica, demonstrando que essas questões permeavam o ambiente intelectual e as querelas do período.

Schwarz escreveu o texto em meio ao período ditatorial no Brasil (1964 - 1985) que condensou, segundo alguns estudiosos, a lógica de um Estado Plutocrático (NOVAIS e MELLO, 1998, p. 651) que, culminando com o Ato-Institucional de 1968, legitimou e deflagrou uma onda de repressão pelo país. O começo dos anos 1970 demarcou o afã do neoliberalismo, também implementado na lógica controversa entre interesse de mercado e justiça social no Chile presidido pelo ditador Pinochet desde 1973. Nesse contexto é significativo que Schwartz tenha esboçado reflexões sobre a pertinência, o "lugar", do liberalismo na formação histórica do Brasil - mais precisamente no século XIX, berço do Estado-Nação moderno.

Se nos detivermos ao artigo de Schwarz, é possível constatar que o autor não afirmou exatamente que as ideias estavam fora do lugar, mas utilizou-se da sensação,

\footnotetext{
${ }^{12}$ O texto deriva da tese de doutorado defendido por Schwarz na Universidade de Paris III, Sorbonne. Depois foi publicado em Estudos Cebrap e incorporado ao livro Ao Vencedor as Batatas: forma literária e processo social nos inícios do romance brasileiro, lançado em 1977.

${ }^{13}$ Ricupero a considerou como "uma das formulações mais atacadas, e mal compreendidas, da crítica da cultura brasileira". (RICUPERO, 2008, p. 59).
}

\section{GANPHLAC}

Revista Eletrônica da ANPHLAC, ISSN 1679-1061, №. 24, p. 324-353, Jan./Jun., 2018.

http://revista.anphlac.org.br 
comum ao Oitocentos no Brasil, e em grande parte da América Latina, de que as ideias estavam em descompasso com a realidade. O "nó" histórico se daria na conjunção da escravidão e do liberalismo na sociedade do século XIX, convivendo no que o autor denominou uma "comédia ideológica" no Brasil. Porém, Schwarz partiu dessa sensação de descompasso para a análise da sociedade da época, mais propriamente da Literatura. Sustentamos essa interpretação baseada na argumentação que Schwarz desenvolveu ao analisar a forma como as ideias liberais agiam no "centro": "lá [na Europa] correspondiam às aparências, encobrindo o essencial - a exploração do trabalho" (SCHWARZ, 2014, p. 48), não assumindo, dessa forma, um lugar ideal e único às ideias, mas expondo suas contradições. A defesa de uma apropriação ideológica empreendida na periferia também foi lembrada pelo autor, ao considerar que "Ao estudá-lo, vimos que difere do europeu, usando embora o seu vocabulário. Portanto, a própria diferença, a comparação e a distância, fazem parte de sua definição" (SCHWARZ, 2014, p. 63), conduzindo ao que Schwarz julgou uma originalidade ideológica e de prática social, como podemos avaliar em: "Submetidas à influência do lugar, sem perderem as pretensões de origem, gravitavam segundo uma regra nova, cujas graças, desgraças, ambiguidades e ilusões eram também singulares." (SCHWARZ, 2014, p. 60).

Nesse sentido, mais do expressarem um fato, as ideias fora do lugar “[...] indicam um processo de formação, que se complementaria na forma..." (RICUPERO, 2008, p. 64). Ricupero considerou que Schwarz buscou explicar a "torção" entre forma e formação de um país "periférico", que se utilizou de formas das Metrópoles, como o romance, o sistema parlamentar, as formas jurídicas, aspirando ao status de civilidade. $\mathrm{O}$ autor defendeu que "no entanto, suas condições sociais teriam pouco em comum com as que produziram originalmente essas formas..." (RICUPERO, 2008, p. 64-65), configurando assim a divergência, ou a sensação de divergência.

Não obstante, a interpretação que Roberto Schwarz não defendeu as "ideias fora do lugar" não inviabiliza algumas críticas pertinentes ao texto. Existem contradições que justificam algumas controvérsias suscitadas. Do ponto de vista histórico, Schwarz argumentou que a sensação de que as ideais estavam foram do lugar criou a comédia ideológica porque o teste da realidade não parecia importante (SCHWARZ, 2014, p. 50). Ora, se as ideias circulavam, como discurso e prática, eram porque estavam

\section{GANPHLAC}

Revista Eletrônica da ANPHLAC, ISSN 1679-1061, №. 24, p. 324-353, Jan./Jun., 2018.

http://revista.anphlac.org.br 
engendradas na dinâmica social e política, sendo parte dessa realidade. Portanto, ao afirmar que a ideologia do século XIX não descrevia nem falsamente a realidade (SCHWARZ, 2014, p. 53), o autor contradisse a prerrogativa de que a originalidade da adaptação das ideias liberais era sua suposta incoerência. Para o historiador, esse descompasso, essa aparente falsificação, constitui um elemento muito importante da construção de uma identidade nacional, das instituições, da consciência social. A adoção de ideias que, num primeiro olhar, estariam "fora do lugar", enquanto uma escolha deliberada da sociedade, deve ser compreendida como uma fonte histórica da mesma sociedade que a "rejeitou" na sua originalidade. Nesse sentido, as ideias descrevem a realidade no qual estão inseridas, sendo muito mais apropriado analisar as práticas, apropriações, meandros e contradições das ideias em cenários distintos do que o fatalismo da incompatibilidade.

Ainda no tocante à metodologia, o autor errou ao não perscrutar o caminho da circulação das ideias, de forma parecida ao empreendido por Salazar Bondy. Schwarz insistiu na incompatibilidade das ideias com a estrutura, do liberalismo com a escravidão, dos discursos com a economia, subvertendo as ideias ao plano refratário da estrutura que a sustentaria. Uma relação dialética foi substituída por uma dimensão hierárquica e de causa e efeito. Essa relação de causalidade engendraria uma noção de exterioridade entre os termos, pensados como as nações metropolitanas, sedes do capitalismo, e a periferia, dependente. Daí deriva, na visão de Franco, a caracterização de modos de produção essencialmente díspares e "o processo social referido a algo de permanente e diverso do Capitalismo e que muda sob seu impacto" (FRANCO, 1976, p. 61). Nesse labirinto teórico, a Teoria da Dependência traria a expressão dessa relação imutável de diferenciação do processo de consolidação do capitalismo, criando polos que se organizam de forma hierárquica e linear, negando uma ideia de processo e mutabilidade. Não obstante, devemos salientar que a crítica feita por Franco foi considerada pelos autores vinculados à Teoria da Dependência que buscaram tornar essa relação mais complexa, ainda que adotando o prisma conceitual da dependência. Importante ressaltar também a importância dos teóricos da dependência, precedidos por Mariátegui e Caio Prado Junior, na formulação de um pensamento marxista latinoamericano (RICUPERO, 1998, p. 71).

\section{CANPHLAC}


Afirmar a complexidade da associação analítica centro/periferia no tocante à caracterização do capitalismo, referenda o estudo da dinâmica e circulação das ideias, com relativa autonomia. $\mathrm{O}$ debate sobre o olhar atento ao desenvolvimento interno, suas idiossincrasias, numa concepção de processo histórico, pode ser apontado como um elemento de aproximação com a vertente hispânica da História das Ideias. Ambas as discussões teóricas convergem na afirmação da necessidade de uma análise da realidade que se atente ao "periférico", mais especificamente a América Latina e sua comunicabilidade com as ideias "de fora". Patrícia Funes considerou que provavelmente em nenhum outro lugar do mundo a questão do universal/particular, original/cópia, tenha permeado as reflexões sobre as ideias políticas como na América Latina (FUNES, 2014, p. 10). Por conseguinte, ponderou que essa discussão está em curso desde o rompimento do Pacto Colonial e da constituição dos Estados-Nacionais, estando “[...] muy ligada a la decepción o a cierto escepticismo frente a los resultados de esa operación de translación acrítica o excesivamente esperanzada de sistemas ideológicos generados en otras sociedades y contextos.” (FUNES, 2014, p. 70). Na década de 1960 e 1970, refletir sobre esse processo de formação reverberou na afirmação de uma libertação possível. A afirmação dessa libertação assumiu diversas facetas, em diferentes contextos, sendo o debate intelectual na América Latina um cenário privilegiado dessas disputas.

\section{Teologia e Filosofia da Libertação}

Os debates sobre o conceito de Libertação foram fundamentais na articulação de duas escolas teóricas que buscaram desenvolver um pensamento latino-americano: a Teologia da Libertação e a Filosofia da Libertação ${ }^{14}$. A vertente teológica precedeu a filosófica, tendo como possível marco formal a publicação de Teologia da Libertação: perspectivas (1971), do teólogo peruano Gustavo Guiterréz, que "batizou” o movimento e se tornou uma referência. Ao longo das décadas de 1970 e 80, vários teólogos, como Juan Luis Segundo (Uruguai), John Sobrino (El Salvador), Hugo Assmann e Leonardo Boff (Brasil), Pablo Richard (Chile, Costa Rica), José Coblim (Bélgica, Brasil), entre

\footnotetext{
${ }^{14}$ Uma importante referência poderia ser apontada na Psicologia da Libertação, mas optamos por não abordá-la pelo delineamento temático e as questões que recortamos para esse artigo.
} 
outros, escreveram obras sobre a Teologia da Libertação, pautando o engajamento social dos cristãos, reformas eclesiásticas, a relação entre política e igreja, e temas do universo teológico, como a escatologia, hermenêutica bíblica e cristologia. Questões abordadas, muitas vezes, de forma dialética.

A Teologia da Libertação se pautou no que Michael Löwy denominou Cristianismo da Libertação, “[...] resultado de uma combinação ou convergência de mudanças internas e externas à Igreja que ocorreram na década de 1950...” (LÖWY, 2016, p. 84). Portanto, a elaboração teórica seria a reflexão sobre a práxis que se desenvolvia no subcontinente, ainda que sejam constituídas de matizes específicas, a exemplo das Ações Católicas e o posterior surgimento das Comunidades Eclesiais de Base (CEBs). Um plano de fundo mais geral seria o movimento de aggiornamento da Igreja Católica, que culminou no Concílio Vaticano II (1962 - 65), adensando os elementos da Doutrina Social da Igreja que, desde a publicação da Rerum Novarum (1891), suscitou um importante debate teológico sobre questões sociais e políticas na sua relação com a Igreja.

O estabelecimento de redes intelectuais e conexões latino-americanas com a Europa e Estados Unidos deve ser ressaltado, confluindo com o fomento às ciências sociais na América Latina no pós Segunda Guerra. (CORTÉN, André, 2004 e MALIK, 2007, p. 442-452) A exemplo do CELAM (Conselho Episcopal Latino-Americano), criado em 1955 e que congregou, num órgão de articulação da Igreja latino-americana, o clero da região. Em um primeiro momento próximo aos sacerdotes vinculados à Teologia da Libertação, a partir dos anos 1970 o Conselho assumiu uma direção conservadora. Um ponto de inflexão importante nesse processo foi a II Conferência Episcopal latino-americana de Medellín (Colômbia) em 1968. As Conferências Episcopais, organizadas pelo CELAM, não possuem uma periodicidade fixa. A primeira, que fundou o Conselho, foi realizada no Rio de Janeiro, em 1955. Após Medellín, o terceiro encontro foi sediado em Puebla (México, 1979), depois São Domingo (República Dominicana, 1992) e a última em Aparecida (Brasil, 2007).

Para uma análise um pouco mais detida, optamos analisar, brevemente, um documento que consideramos abranger parte significativa do contexto intelectual dos teólogos e bispos latino-americanos: as conclusões redigidas ao final da II Conferência de Medellín. O texto da Conferência é dividido em 11 seções temáticas, agrupados em

\section{GANPHLAC}


três partes. Cada seção foi redigida por uma comissão de bispos de diferentes dioceses e arquidioceses latino-americanas, assumindo desde posicionamentos mais alinhados com a Teologia da Libertação até caracterizações conservadoras, a depender de fatores como a composição, debate e temática de cada comissão, as demandas em torno de cada assunto, a redação do texto e a votação subordinada à Assembleia de bispos, etc. Assim, forjou-se um atípico documento eclesiástico no qual diferentes vozes são perceptíveis e cuja construção é permeada por complexos arranjos políticos.

Cada conferência, que conta com a presença do Papa na abertura (com exceção da primeira), tem uma proposta de discussão. A de Medellín foi “A Igreja na presente transformação da América Latina à luz do Concílio Vaticano II". As Conclusões de Medellín são comumente tidas como espécie de "manifesto" da Teologia da Libertação, embora não estivessem presentes apenas sacerdotes ligados a ela nesse encontro. É possível observar um tom progressista, ainda que perpassado por contradições.

Todas as seções das Conclusões de Medellín iniciam com um preâmbulo sobre as mudanças em curso na América Latina. Na Mensagem aos povos da América Latina Nossa palavra, sinal de compromisso, escrita ao término da redação das Conclusões, ficou explicitada a caracterização do presente como uma "conjuntura decisiva", que determinaria o futuro (CONSELHO EPISCOPAL LATINO-AMERICANO, 2010, p. 27). Dessa forma, debateu-se o papel da Igreja nesse "nó" histórico que foi alçado aos homens latino-americanos. Decorreu-se a vinculação da história da salvação a essa etapa histórica da América Latina, considerando uma concepção escatológica, de um horizonte salvífico preexistente, mas que deve estar em conformidade com o momento histórico, que é tido, ao longo do documento, como urgente, decisivo, imediato, inédito. A Libertação seria a mensagem que a Igreja deve anunciar em meio às intempéries que se firmam no tempo histórico latino-americano, e perpassou, praticamente, todas as considerações temáticas da Conferência.

Medellín impulsionou, e também foi constituída, por um "chamamento" para uma reflexão teológica que estivesse atrelada à realidade latino-americana. Podemos observar isso claramente, na seção sobre Pobreza da Igreja

O episcopado latino-americano não pode ficar indiferente às tremendas injustiças sociais existentes na América Latina [...] um surdo clamor nasce de milhões de homens, pedindo a seus pastores uma libertação que não lhes chega de nenhuma parte [...] A Igreja da América Latina, dada as condições

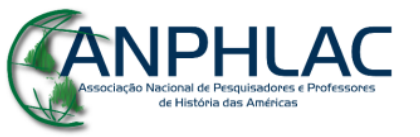

Revista Eletrônica da ANPHLAC, ISSN 1679-1061, №. 24, p. 324-353, Jan./Jun., 2018.

http://revista.anphlac.org.br 
de pobreza e subdesenvolvimento do continente, sente a urgência de traduzir esse espírito de pobreza em gestos, atitudes e normas, que a tornem um sinal mais lúcido e autêntico do Senhor. (CONSELHO EPISCOPAL LATINOAMERICANO, 2010, p. 195 e 198).

É notório que os prelados presentes no encontro sentiam uma necessidade de exercer o magistério de forma articulada com a atuação social. Mas também assumiram certo vanguardismo na condução do processo libertador, além de orientarem a "purificação" da religiosidade popular, de forma a condizer com seus postulados (CONSELHO EPISCOPAL LATINO-AMERICANO, 2010, p. 111-114), revelando contradições inerentes à afirmação conceitual e à importância de se relativizar maniqueísmos e simplificações.

O tom do discurso também chama a atenção, ainda mais se levarmos em conta que os documentos eclesiásticos, normalmente, possuem uma conotação menos incisiva e mais conciliatória. O projeto de libertação do povo seria um ideal que articularia essa nova leitura da realidade à afirmação de um pensamento teológico latino-americano. Cabe destacar a proximidade com a Teoria da Dependência, no que tange a análise político-econômica. Ainda que a Teoria da Dependência tenha ramificações distintas, sendo constituída por diferentes relações com o Marxismo, a perspectiva revolucionária, o diagnóstico e o programa econômico - grosso modo, a rejeição de um viés desenvolvimentista pela almejada mudança estrutural, assumindo as polaridades interligadas e hierarquizadas na geopolítica e relações econômicas - influenciaram na forma como a realidade latino-americana foi interpretada.

A própria formação do clero latino-americano deveria abordar essa necessidade, tendo sido recomendado "[...] importância particular ao estudo e investigação de nossas realidades latino-americanas em seus aspectos religioso, social, antropológico e psicológico.” (CONSELHO EPISCOPAL LATINO-AMERICANO, 2010, p. 190). Os espaços de debate intelectual e circulação de ideias nos quais o conceito de Libertação e um pensamento teológico latino-americano foram abordados, tiveram um período consideravelmente exitoso após Medellín, motivados e circunscritos ao próprio CELAM, mas também às Universidades Católicas (muitas surgidas na América Latina nos anos 1940 e 50), ao crescimento de revistas e aos encontros teológicos e eclesiásticos (SARANYANA, 2005, p. 33-37; DUSSEL, 1983, p. 177), além dos movimentos sociais aos quais segmentos da Igreja se engajaram, que nesse período se

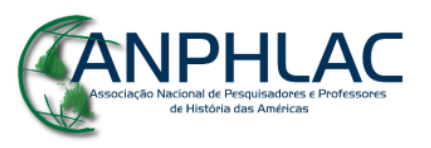


organizaram de diversas formas, desde movimentos sacerdotais socialistas e guerrilheiros à ações pastorais

A Conferência de Medellín foi fundamental no estabelecimento da Teologia da Libertação e uma etapa importante na consolidação de um novo pensamento teológico latino-americano. Todavia, na década de 1970, ocorreu um acirramento do debate intelectual sobre o significado da Libertação e quais as nuances da relação da Igreja com a sociedade, que passou a debater o envolvimento com a política (em meio ao autoritarismo das Ditaduras Militares) até a reorganização das relações e estruturas eclesiásticas (após o Concílio Vaticano II). A Conferência seguinte, em Puebla (México), 1979, é insigne do intenso debate no qual a Igreja esteve envolvida e da resistência que o Vaticano e uma ala conservadora da Igreja latino-americana impuseram a essa "nova teologia", tida como perniciosa, pouco afeita à espiritualidade.

Considerando as conclusões das conferências de Medellín e Puebla, além de outros documentos que versaram sobre a "questão social”, Alexandre Queiroz esboçou uma tipologia acerca dos debates e sentidos atribuídos à Libertação na Igreja latinoamericana do período. Ainda que haja diálogos e sobreposições entre elas, abrangeriam os conceitos de: Libertação Espiritual, afeito aos postulados mais tradicionais da teologia, designando o reino de Deus como o reencontro com a natureza humana e a liberdade - orientação hegemônica da Igreja, entrando em atrito com posições mais afeitas a reivindicações sociais e políticas a partir da década de 1950, tendo um recrudescimento ao longo dos anos 70; Libertação Dialética, conforme elaborado em Medellín, assumindo uma concepção dialética da Libertação entre o plano salvífico mundano e pós-morte, mais próximo à Teologia da Libertação; e Libertação Marxista, pautado na nominal defesa do Marxismo e marcado por uma perspectiva revolucionária, que congregou uma pequena, mas significativa, parte do clero, principalmente entre as Conferências de Medellín e Puebla. (QUEIROZ, 2018).

Dentre uma visão contrária à Teologia da Libertação, o influente cardeal colombiano Alfonso Lopéz Trujillo considerou que a relação que essa vertente teológica possuía com Medellín era o "mais valioso e relativamente original", mas o contato com o Marxismo, assim como o pensamento teológico europeu (a exemplo de Paul Blanquart e Julio Girardi), constituiu uma amálgama no qual a originalidade é controversa, não sendo "producto vernáculo ni característico de nuestra reflexión

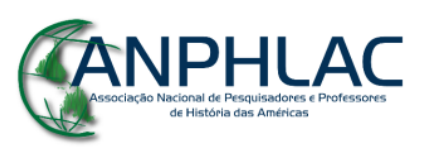

Revista Eletrônica da ANPHLAC, ISSN 1679-1061, №. 24, p. 324-353, Jan./Jun., 2018.

http://revista.anphlac.org.br 
teológica.” (TRUJILLO, 1980, p. 235). Dessa forma o sacerdote desconsiderou as apropriações teóricas pelos intelectuais e sacerdotes latino-americanos, considerando-os como "ideias fora do lugar", e estabeleceu um cânone questionável do que seria a "nuestra reflexión teológica", apregoando uma "legítima" Teologia da Libertação, reduzindo o que consideramos uma das mais importantes características dessa teoria, sua articulação intelectual.

A Teologia da Libertação também teve relevantes contatos com a Pedagogia do Oprimido de Paulo Freire (além das citações nominais a Freire por alguns teólogos da libertação, a seção sobre educação das Conclusões de Medellín, ao referir-se a uma Educação Libertadora, atesta este diálogo) e influenciou o debate filosófico sobre a pertinência das questões latino-americanas nos cânones. Essa relação, em grande medida, foi intermediada por Enrique Dussel, que coordenou o CEHILA (Comissão de Estudo da História da Igreja na América Latina) ${ }^{15}$. Mas antes de abordamos a reflexão dusseliana, esboçaremos os contornos gerais da Filosofia da Libertação.

A exemplo da Teologia da Libertação, o "marco fundacional" da Filosofia da Libertação também pode ser demarcado por um encontro entre os pares. Na Argentina, em 1970, o II Congresso Nacional de Filosofia teve como tema "América como problema", e buscou romper com o estilo europeu de fazer e pensar a Filosofia, lançando as bases sob as quais se desenvolveu a Filosofia da Libertação. Depois deste Congresso $^{16}$, um grupo de intelectuais passou a se reunir anualmente em Córdoba construindo um ambiente crítico, no qual se debateu a

\footnotetext{
${ }^{15}$ O CEHILA, fundado em 1973, ambicionou escrever uma História da Igreja (principalmente Católica, ocasionalmente a Protestante) na América Latina, pautando a libertação como força motriz. Realizou diversos encontros e publicou muitos livros. O Centro congregou nomes como José Oscar Beozzo, Samuel Silva Gotay, Pablo Richard, Eduardo Hoornaert, Rodolfo R. de Roux, entre outros - além do próprio Enrique Dussel. Pelos limites do artigo, não nos aprofundaremos na análise histórica empreendida pelo CEHILA, mas o texto de Londoño (LONDOÑO, Fernando Torres. Produção historiográfica sobre a Igreja da América Latina nos últimos 50 anos. In: HOORNAERT, Eduardo. História da Igreja na América Latina e no Caribe - 1945-1995. O debate metodológico. São Paulo: Vozes, 1995) e o primeiro volume da Coleção que a própria comissão lançou sobre a História da Igreja na América Latina (COMISION DE ESTUDIOS DE HISTORIA DE LA IGLESIA EN AMERICA LATINA. Historia General de la Iglesia en América Latina. Tomo I - Introducción General a la Historia de la Iglesia en América Latina. Salamanca: Sígueme, 1983) conferem um panorama dessa proposta.

${ }^{16}$ Outro evento fundamental nessa fase de construção da Filosofia da Libertação foi a Segunda Jornada Acadêmica da Faculdade jesuíta de Filosofia e teologia San Miguel, com a temática "liberación latinoamericana", em 1972.
}

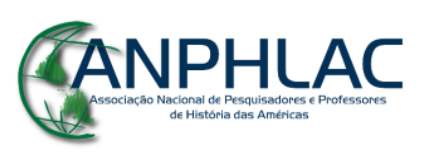

Revista Eletrônica da ANPHLAC, ISSN 1679-1061, №. 24, p. 324-353, Jan./Jun., 2018.

http://revista.anphlac.org.br 
[...] cuestión de la experiencia ontológica fundamental y su situacionalidad histórica, se trató sobre todo de las mediaciones histórico-sociales y filosófico-históricas necesarias para pensar dicha experiencia y el proceso de liberación latinoamericano. (ARDELLES et al., 1973, p. 271)

Em 1973, as convergências possíveis e as questões pautadas nesse grupo foram expressas no livro coletivo ${ }^{17}$ Hacia una Filosofia de la liberación latinoamericana. No final do livro, à "manera de manifesto", encontra-se um breve comentário sobre seus fundamentos.

Filosofía de la liberación entre nosotros es la única filosofía latinoamericana posible, que es lo mismo que decir que es la única filosofía posible entre nosotros. El pensar filosófico que no tome debida cuenta crítica de sus condicionamientos y que no se juegue históricamente en el esclarecimiento y la liberación del pueblo latinoamericano es ahora, pero lo será mucho más en el futuro, un pensar decadente, superfluo, ideológico, encubridor, innecesario. (ARDELLES (et al), 1973, p. 281).

O tom militante, que assumiu uma postura de ineditismo e legitimidade no que tange as prerrogativas elencadas pelo grupo, fundamentou-se na acolhida pelos oprimidos, num programa que visou uma declarada e fundamentada libertação. $O$ Manifesto, parte do delineamento de uma concepção filosófica latino-americana, foi lançado num momento de recrudescimento do Peronismo na Argentina. Em meados dos anos 1970, precedido por uma intensa instabilidade e pelo Golpe Militar de 1966, o Peronismo se rearticulou politicamente com a posse de Juan Domingo Perón em 1973 (possível pela renúncia de Héctor José Cámpora). O aceno a uma política nacionalista e trabalhista, marca da primeira fase peronista e respaldada por grande parte dos argentinos, transformou-se na desilusão póstuma da morte de Perón, no ano seguinte à sua vitória eleitoral, e ao governo pouco carismático de Isabelita Perón. Dessa forma, a articulação em torno de uma Filosofia da Libertação se inscreve nos debates sobre a volta do Peronismo, que envolveu desde o entusiasmo em torno de um líder populista e controverso até o acirramento das posições políticas nesse cenário. O arremate autoritário desse contexto, também vivido em outros países latino-americanos no

\footnotetext{
17 Assinam o livro: Mario Casalla, Horacio Cerruti Guldberg, Carlos Cullen, Enrique Dussel, Rodolfo Kusch, Arturo Andrés Roig, Juan Carlos Scannone, Hugo Assmann, Horácio Ardilles, Julio de Zana, Antonio Kinen, Daniel Guillot, Diego F. Pró, Rodolfo Kusch e Agustín de la Riega.
}

\section{GANPHLAC}


período, foi o Golpe Militar de 1976, arrastando a Argentina para uma violenta ditadura que perdurou até 1983 .

Além do contexto mais imediato que parte de terras argentinas, a atmosfera intelectual latino-americana teve grande impacto nos debates em torno do desdobramento filosófico de um pensamento latino-americano voltado à sua realidade circunscrita. A própria Teologia da Libertação e a Teoria da Dependência integram ressignificações dos cânones e leituras consolidadas e outorgadas, em alguma medida, para o pensamento latino-americano. Nesse sentido, o conceito de Libertação talvez seja uma de suas expressões mais substanciais. Entretanto, não compreende um campo hermético, embora houvesse a necessidade de delimitar os contornos da reflexão filosófica para o ambiente que se propunham dialogar. Nessa acepção, é importante salientar o impacto da recepção latino-americana de Os Condenados da Terra, publicado em 1961 por Frantz Fanon (SIDEKUM, 1983, 163). Nascido na Martinica (Caribe), Fanon engajou-se na luta pela independência Argelina da França, entre 1952 e 1964, refletindo sobre a Violência e Descolonização. Também podemos apontar a crítica do alemão Hebert Marcuse ao pensamento "unidimensional universal", que envolve aceitações acríticas e conformista de estruturas e padrões, consoante em $O$ Homem Unidimensional, de 1964 (DUSSEL, 1983, p. 39).

Em uma abordagem mais ampla, Delvés-Valdés delineou um "movimiento liberacionista”, com segmentações disciplinares, cronológicas e ideológicas, mas que concebeu uma identidade. Em Pensamiento periférico, considerou conexões intelectuais transcontinentais, relacionando as obras de Fanon e Freire, a produção teológica africana - também em diálogo com a teologia negra estadunidense, o movimento Minjung na Coréia do Sul dos anos 1980 e, em certo grau, até a "estratégia” de libertação de Castro e Che Guevara, dentre outros. (DEVÉS-VALDÉS, 2014, p. 487513).

A heterogeneidade nesse agrupamento pode ser explicitada ao analisarmos o caso filosófico. O IX Congresso Interamericano de Filosofia, realizado em Caracas (Venezuela) em julho de 1977, expôs as três grandes correntes do pensamento filosófico latino-americano: a que defendia que a Filosofia envolve, em sua concepção, uma pretensão universal, representado por Miró Quesada e Agustin Basave; a vertente orientada pela realidade particular para a reflexão filosófica, liderada por Leopoldo Zea

\section{CANPHLAC}

Revista Eletrônica da ANPHLAC, ISSN 1679-1061, №. 24, p. 324-353, Jan./Jun., 2018.

http://revista.anphlac.org.br 
e Arturo Ardao; e uma terceira, envolvida na composição de uma Filosofia da Libertação, com Campos Barrantes e José Jara, que tinha em Enrique Dussel, a partir de 1970, o desenvolvimento de seus postulados. (SOFISTE, 2005, p. 8)

Dentre essas tendências, a que prevaleceu e ganhou maior projeção foi a vertente encabeçada pelo argentino, radicado no México, Enrique Dussel. Em Filosofia da libertação - crítica à ideologia da exclusão, Dussel esboçou alguns dos postulados de sua concepção filosófica, que o autor centrou não apenas na temática da liberdade, mas como um programa de libertação, isso é, assumindo como tarefa intrínseca da reflexão filosófica o engajamento sociopolítico.

A origem desse postulado filosófico não é a imediata afirmação do Eu, diante das variadas experiências opressivas, mas, antes, a reflexão e o descobrimento da existência nas suas condições, uma "interpelação primitiva" em que "uma resposta é responsável pelo apelo do outro". Portanto, a consciência reflexiva precede uma responsabilidade sobre o "outro". Desenvolve-se assim uma ética da alteridade, fundamento primordial para que se conceba um elo de justiça entre os homens, descortinando um projeto de libertação (DUSSEL, 1995, p. 19).

Dussel também retomou a crítica a Bondy, ao considerar que, diante de uma situação de opressão, como caracterizada na América Latina, haveria a impossibilidade de condições de interpretação de ordens "subjetivas, objetivas, hermenêuticas, textuais, etc.”. Mas o ponto de partida da Filosofia da Libertação tratou de inverter a questão e afirmar na leitura crítica, por parte dos oprimidos da realidade que estão inseridos, uma ação libertadora (DUSSEL, 1995, p. 31). Em suma, a filosofia dusseliana teve como

[...] ponto de partida uma realidade regional própria: a pobreza crescente da maioria da população latino-americana; a vigência de um capitalismo dependente, que transfere valores para o capitalismo central; a tomada de consciência da impossibilidade de uma filosofia autônoma dentre tais circunstâncias; a existência de tipos de opressão que estão a exigir não apenas uma filosofia da "liberdade", mas uma filosofia da "libertação"... (DUSSEL, 1995, p. 45-46)

Podemos observar a adoção de termos muito propagados pelo corolário da Teoria da Dependência, como capitalismo dependente e central, retomando o quadro centro/periferia que transcenderia o nível econômico e assumiria uma subjeção também das consciências, ao qual exigia uma resposta imediata, enérgica e autóctone: a Filosofia

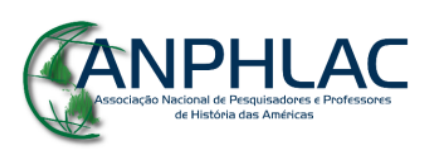

Revista Eletrônica da ANPHLAC, ISSN 1679-1061, №. 24, p. 324-353, Jan./Jun., 2018.

http://revista.anphlac.org.br 
da Libertação. Dentro dessa perspectiva, ficam excluídas alternativas de desenvolvimento filosófico para a América Latina, dado seu quadro de dependência. Considerando o "capitalismo tardio" da região, uma reflexão crítica que não se engajasse na desconstrução dessa relação de dominação, estaria fadada a repetição e o fracasso. Em suma, ou a filosofia latino-americana seria a Filosofia da Libertação, ou não seria.

A Filosofia da Libertação teve uma contribuição muito importante na releitura do Marxismo, pensada nas questões latino-americanas. Tomando Marx como um crítico da alteridade, e apoiando-se na concepção dialética, Fornet Betancourt considerou que a crítica de Dussel e do Marxismo na América Latina nos anos 1970

[...] contribui para o esclarecimento das contradições teóricas para a inovação contextualizada para a América Latina, do modo de pensar crítico, dialético, baseado em Marx, sendo, assim, já parte de um marxismo latinoamericano. ${ }^{18}$ (FORNET-BETANCOURT, 1995, p. 317)

Tal afirmação encadeava-se na reflexão que, desde começo do século XX, problematizava a relação entre postulados do Marxismo e a realidade latino-americana.

\section{Considerações Finais}

Trilhamos os contornos transnacionais de um pensamento latino-americano que estabeleceu um tipo de crítica, nos anos 1960 e 70, identificado como libertadora, revolucionária e estrutural. Essa vertente interpretativa marcou uma leitura do "homem latino-americano" sob o binômio dependência/libertação, como conceitos de análise e atuação política, social e teológica. Antonio Candido assinalou que "no pensamento latino-americano, a reflexão sobre a realidade social foi marcada, desde Sarmiento, pelo senso de contrastes e mesmo dos contrários.” (CANDIDO, 2011, p. 12). Roig também corroborou essa visão, afirmando que essa é uma continuidade peculiar do pensamento latino-americano, do século XIX até a atualidade.

\footnotetext{
$18 \mathrm{O}$ autor considerou que Enrique Dussel “[...] liberta-se do antimarxismo católico conservador, especialmente o argentino, para uma nova recepção de Marx, a partir de seu exílio no México, no final dos anos 1970.”(FORNET-BETANCOURT, 1995, p. 299).
}

\section{CANPHLAC}

Revista Eletrônica da ANPHLAC, ISSN 1679-1061, №. 24, p. 324-353, Jan./Jun., 2018.

http://revista.anphlac.org.br 
Los problemas de "dependencia-independencia", "dominación-liberación", han desempeñado un papel determinante respecto de las formas y el uso del pensamiento filosófico en todo el continente. (ROIG, 1986, p. 48)

Libertação, dependência, entre outros, seriam "conceitos chave" para entender o ambiente político-social da América Latina porque a História das Ideias teria buscado, segundo Roig, conceitos “integradores” e não opressivos (ROIG, 1986, p. 71). Entretanto, devemos também entender as contradições que permeiam essa discussão conceitual e a afirmação do pensamento latino-americano, visto que as ideias não são unívocas e lineares.

Nessa conjunção, certos autores, metodologias e perspectivas foram rechaçados por terem sido entendidos como enunciados legitimadores de uma natureza delimitadora da consciência, opressivos, conforme se referiu parte da bibliografia do período. Buscou-se um afastamento da dualidade intelectual característica do ambiente político e social latino-americano desde o século XIX, a disputa entre liberais e conservadores. Ainda que essas categorias tenham apresentado uma diferenciação muito grande nos países da região, e tenham inspirado apropriações peculiares, essas duas balizas foram postas de lado nesse período, numa forma de rejeitar o status quo e propor uma nova via, considerando que na América Latina as ideologias de esquerda passaram a integrar os debates intelectuais no século XX, tendo seu momento de maior expressividade na década de 1960, compondo esse novo cenário intelectual.

Outros postulados, como o eurocentrismo, o universalismo e o essencialismo, foram alvo de crítica e desconstrução por meio de dois pressupostos básicos desenvolvidos no âmbito da História das Ideias, Teologia da Libertação e Filosofia da Libertação: a dialética e o historicismo. A Teologia da Libertação, por exemplo, se baseou nesse pressuposto para afirmar que

[...] toda la verdad sobre el mundo se desprende de él mismo y que no existen verdades preestabelecidas, porque aquello que és, lo és en proceso y resulta de la dialética misma de la historia; la verdad siempre está por hacerce. (GOTAY, 1986, p. 120)

Essa observação é particularmente sensível porque a Teologia parte de concepções dogmáticas, que prezam a tradição, como uma essência revelada aos homens que deve atravessar o tempo, sobrepondo-o. Entretanto, notamos que o texto se refere a uma "verdad siempre por hacerce", denotando que não é uma ideia de verdade

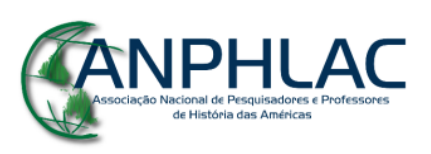

Revista Eletrônica da ANPHLAC, ISSN 1679-1061, №. 24, p. 324-353, Jan./Jun., 2018.

http://revista.anphlac.org.br 
totalizadora e essencialista que é totalmente desconsiderada, mas um sentido específico. Paradoxalmente, tanto o movimento da História das Ideias, como os membros da Teologia da Libertação e da Filosofia da Libertação não poderiam abrir mão tão facilmente de uma "verdade", enquanto categoria discursiva e ideológica. Trataram de apropriá-la à sua metodologia e revestir sua análise dialética do processo histórico latino-americano - numa perspectiva teleológica - por meio de uma "verdade" que nasceria do contato com a realidade, levando em conta a experiência e um novo entendimento de natureza e identidade, respaldado pelo passado comum do subcontinente. A análise da realidade traria à superfície a "real essência" do homem latino-americano e os rumos da História. As ideias que aqui circularam teriam um propósito, conduzir ao processo libertador.

Nesse sentido, "verdad por hacerce" seria uma nova epistemologia que se elucidaria pela Libertação, latente na consciência latino-americana, resguardada por essa crítica emergente. A validade e/ou realidade das ideias, pela linha da dicotomia do pensamento latino-americano esboçado por Candido e Roig, seriam pares dialéticos, e a Libertação uma síntese que deveria supor uma totalidade, incorruptibilidade ou verdade absoluta, que estaria respaldada pela "natureza" do homem latino-americano ou pela própria História. Esse parece ter sido um dos grandes desafios epistemológicos para as agendas ideológicas e disciplinares que se desenvolviam, e motivos de críticas.

Esses movimentos que buscavam a afirmação de um pensamento latinoamericano se posicionaram como portadores de uma mensagem imprescindível e inquestionável, pois, fora dos ditames da "libertação" teológica, filosófica e histórica (ou epistemológica), voltar-se-ia ao ciclo da repetição da dependência, a subordinação à dominação. Mas devemos considerar a dificuldade de estabelecimento dessas ideias no período destacado e em suas respectivas áreas, tendo suscitado questões até hoje relevantes. Ainda que a afirmação desse pensamento latino-americano possa parecer uma "verdade absoluta", é imprescindível pensar no contexto em que ele se afirmou, do qual destacamos: o pensamento eurocêntrico, a difícil realidade socioeconômica, as ditaduras que se instauravam no continente, o ambiente da Guerra Fria e outros fatores (não poderíamos aqui elencar as dificuldades em cada área, mas elas são importantes). Além do seu legado crítico, imprescindível ao considerarmos o percurso das ideias na América Latina na segunda metade do século XX. Essa perspectiva histórica serve para

\section{CANPHLAC}


apontar uma etapa fundamental no questionamento e reformulação das ideias na América Latina e na percepção de um horizonte no qual a consciência crítica fundamentaria o que se denominou pensamento latino-americano.

\section{Referências Bibliográficas}

ARDILLES, Horácio et al. Hacia una Filosofía de la liberación latinoamericana. Buenos Aires: Bonum, 1973.

BONDY, Augusto Salazar. ?Existe una filosofia de Nuestra America? Disponível em: http://www.olimon.org/uan/bondy.pdf. Acesso em: 25/07/2016.

CANDIDO, Antonio. O Significado de Raízes do Brasil. In: HOLANDA, Sérgio B. Raízes do Brasil. São Paulo: Companhia das Letras, 2011.

CARVALHO, Eugênio Rezende de. A dupla dimensão do movimento latino-americano de história das ideias. Revista Brasileira de História. São Paulo, v. 31, nº 61, 2011.

CARVALHO, Eugênio Rezende de. A Polêmica entre Leopoldo Zea e Augusto Salazar Bondy sobre a existência de uma filosofia latino-americana (1969-1969). Ideias. Campinas (SP), n. 7, $2^{\circ}$ semestre (2013).

CARVALHO, Eugênio Rezende de. Pensadores da América Latina: o movimento latino-americano de História das Ideias. Goiânia: Editora UFG, 2009.

CERRUTI, H. Guldberg. Filosofia da Libertação. Cidade Do México: Siglo Vientiuno, 1983 apud SIKEDUM, Antonio. O programa do diálogo da ética do discurso e a Filosofia da Libertação. Libertação-Liberación. CEFIL, Campo Grande, v. 3, 1993.

CONSELHO EPISCOPAL LATINO-AMERICANO. Conclusões da Conferência de Medellín - 1968: trinta anos depois, Medellín é ainda atual? São Paulo: Paulinas, 2010.

CORTÉN, André. El establecimiento de una red de la teología de la liberación. In: BASTIAN, Jean-Pierre. La Modernidad Religiosa. Europa y América Latina en perspectiva comparada. Cid. do México: FCE, 2004.

DEVÉS-VALDÉS, Eduardo. Pensamiento periférico: Asia - África - América Latina Eurasia y algo más. Una tesis interpretativa global. Buenos Aires: CLACSO; IDEAUSACH, 2014.

DUSSEL, Enrique. De Medellín a Puebla: uma década de sangue e esperança. Vol. III. Em torno de Puebla - 1977-1979. São Paulo: Loyola, 1983.

DUSSEL, Enrique. Del esceptico al cinico. Libertação-Liberación. CEFIL, Campo Grande, v. 3, 1993.

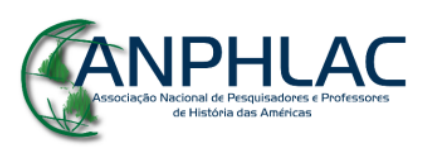

Revista Eletrônica da ANPHLAC, ISSN 1679-1061, №. 24, p. 324-353, Jan./Jun., 2018.

http://revista.anphlac.org.br 
FORNET-BETANCOURT, Raúl. O marxismo na América Latina. São Leopoldo: Ed. UNISINOS, 1995.

FRANCO, Maria Sylvia Carvalho. As Ideias estão no lugar. Cadernos de Debate I, São Paulo, n. 1, 1976.

FUNES, Patrícia. Historia mínima de las ideas políticas en América Latina. Madrid: Turner; Colégio del México, 2014.

GOTAY, Samuel Silva. El pensamiento religioso. In: ZEA, Leopoldo (Coord.) América Latina en sus ideas. Cidade do México: Editora del siglo vientiuno, 1986.

LOWY, Michael. O que é Cristianismo da Libertação? Religião e Política na América Latina. São Paulo: Perseu Abramo - Expressão Popular, 2016.

MALIK, Tahar Chaouch. La teología de la liberación en América Latina: una relectura sociológica. Revista Mexicana de Sociología, vol. 69, núm. 3, julio-septiembre, 2007.

MYERS, Jorge. Músicas distantes. Algumas notas sobre a história intelectual hoje: horizontes velhos e novos, perspectivas que se abrem. In: NORONHA DE SÁ, Maria E. (Org.) Historia intelectual latino-americana: itinerários, debates e perspectivas. Rio de Janeiro: Ed. PUC-Rio, 2016.

NORONHA DE SÁ, Maria E. Apresentação. In: NORONHA DE SÁ, Maria E. (Org.) Historia intelectual latino-americana: itinerários, debates e perspectivas. Rio de Janeiro: Ed. PUC-Rio, 2016.

NOVAIS, Fernando; MELLO, João Manuel Cardoso. Capitalismo tardio e Sociabilidade moderna. In: SCHWARCZ, Lilia M. História da Vida privada no Brasil: Contrastes da intimidade contemporânea. São Paulo: Companhia das Letras, 1998.

QUEIROZ, Alexandre de Oliveira. A Revolução no Paraíso: Ressignificações do conceito de Libertação na Igreja latino-americana (1968-1979). Dissertação de mestrado - Escola de Filosofia, Letras e Ciências Humanas da Universidade Federal de São Paulo. Guarulhos, 2018.

RICUPERO, Bernardo. Da formação à forma. Ainda as "ideias fora do lugar". Lua Nova, São Paulo, 73, 2008.

RICUPERO, Bernardo. Existe um pensamento marxista latino-americano? In: BARSOTI, Paulo e PERICÁS, Luiz Bernardo. América Latina - história, idéias e revolução. São Paulo: Xamã, 1998.

ROIG, Arturo A. Interrogaciones sobre el pensamiento filosófico. In: ZEA, Leopoldo (Coord.) América Latina en sus ideas. Cidade do México: Editora del siglo vientiuno, 1986.

SANTOS, Luciano dos. Leopoldo Zea, Arthuro Ardao e João Cruz Costa: história das ideias, discursos identitários e conexões intelectuais. Tese de doutorado - Faculdade de

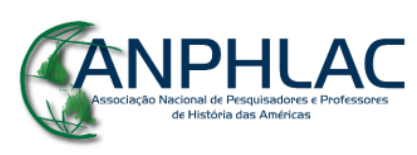

Revista Eletrônica da ANPHLAC, ISSN 1679-1061, №. 24, p. 324-353, Jan./Jun., 2018.

http://revista.anphlac.org.br 
Filosofia, Letras e Ciências Humanas da Universidade de São Paulo. Departamento de História. São Paulo, 2016.

SARANYANA, Josep-Ignasi. Cem anos de teologia na América Latina. São Paulo: Paulinas, 2005.

SCHWARZ, Roberto. As ideias fora do lugar. In: SCHWARZ, Roberto. As ideias fora do lugar - ensaios selecionados. São Paulo: Penguin Classics e Companhia das Letras, 2014.

SIDEKUM, A. Informe. Libertação-Liberación. CEFIL, Campo Grande, v. 3, 1993.

SOBREVILLA, David. Augusto Salazar Bondy y la Filosofía de la liberación latinoamericana. In: AVILA, Rubén Q. (coord.). Actas del congreso sobre Augusto Salazar Bondy. Lima: Instituto de investigación del pensamiento peruano $\mathrm{y}$ latinoamericano, 2014.

SOFISTE, Juarez. Filosofia Latino-americana: filosofia da libertação ou libertação da filosofia? Revista Ética \& Filosofia Política. Vol. 8, nº 1, junho/2005.

TRUJILlO, Alfonso L. De Medellín a Puebla. Madrid: Editorial Catolica, 1980.

URIBE, Jaime J. Frecuencias temáticas de la historiografía latino-americana. In: ZEA, Leopoldo. (Coord.) América Latina en sus ideas. Cidade do México: Editora del siglo vientiuno, 1986.

WEINBERG, Liliana. Leopoldo Zea y América Latina. Anuario de Filosofía Argentina y Americana, $n^{\circ}$ 21/22, años 2004-2005.

WEINSTEIN, Barbara. Pensando a História fora da Nação: a Historiografia da América Latina e o viés transnacional. Revista eletrônica da ANPLHAC, n. 14, jan./jun. 2013.

ZEA, Leopoldo. La filosofía americana como filosofía sin más. Disponível em: http://www.olimon.org/uan/zea.pdf. Acesso em: 25/07/2016.

\section{GANPHLAC}

Revista Eletrônica da ANPHLAC, ISSN 1679-1061, №. 24, p. 324-353, Jan./Jun., 2018.

http://revista.anphlac.org.br 